\title{
Insurance Health companies of a southern region of Colombia: Company behavior and survival 2012-2016
}

This article describes the behavior of insurance health companies registered during 2012 to 2016, from the state of Huila - Colombia. A retrospective observational descriptive study was performed; the source of information was a national database "Registro Único Comercial y Social - RUES"; taking into account only registered health insurance companies, their economic activity, size and location. It was found an inverse association between company size and survival, and a direct association between size and number of companies that are registered under a specific economic activity. This information can be useful for future projects, strategies, interventions for new and established health insurance companies.

\section{Keywords: business success, health companies, health sector, business behavior}

\section{Introduction}

Social ministry of Colombia has changed the health system significantly and also the structure for health workers. Before the Law 100 of 1991, there were three subsystems: social security, public and private health [1].

The social security included the Social Security Institute (SSI), which provided its service throughout the network of public hospitals, and the private subsystem which covered groups that had prepaid or private medicine plans [1-2].

Law 100 of 1993 incorporated a new competition based schemes which regulated market and price mechanisms with the goal of increasing coverage, improving efficiency / quality of services, throughout the adoption of an obligated health insurance plans and a regulated competition scheme [3].

These changes in the health system allowed the creation of the Health Promoter Companies (HPC), the outsourcing of the health service to the Health Care Institutes (HCI), leading to formation of the Small and Medium companies. Although this reform has influenced the formation of many small and medium size companies [4], this puts a big uncertainty for survival in the market National.
Several studies, in different countries, show that $50 \%$ or more of those companies created can survive for at least five years [5-7]. In fact, in OECD countries, about $20-40 \%$ of new firms leave their operation within the first two years of life and only 40 to $50 \%$ survive beyond the seventh year $[8,9]$. There are various factors that determine the company survival: economic environment and capacity to innovate [10-15], growth rate, size and age of companies [16-20], level of concentration and reactibility to market changes $[21,22]$ and making strategic decisions [23,24].

In Latin America there are a similar behavior, according to the national association of commerce of Latin America survival for companies is defined when $50 \%$ or more of those companies created can survive for at least five years. In Colombia only forty percent remain open [25] evidencing that a low company survival $[7,26]$.

However, in Colombia the determinants for company survival are not clear. There have been made several studies about company survival in certain cities of Colombia [27-29], but most of them excludes health companies and have not reached to solid conclusions [30], and have very singular inclusion criteria [31]. Although these studies have established a baseline in Colombia,
Cristian Rincón-Guio ${ }^{1}$, Ana María Mañosca Ramírez ${ }^{2}$, Jesús Roa Polanía ${ }^{3}$, Katherin Torres $\mathrm{P}^{4}$, José D. Charry ${ }^{5 *}$

${ }^{1}$ Department of Engineering, Fundación Universitaria NavarraUninavarra, Colombia

${ }^{2}$ Department of Health Science, Fundación Universitaria NavarraUninavarra, Colombia

${ }^{3}$ Research Department, Fundación Universitaria Navarra- Uninavarra, Colombia

${ }^{4}$ Department of Humanities and Social Science, Fundación Universitaria Navarra- Uninavarra, Colombia

${ }^{5}$ Research Department, Fundación Universitaria Navarra- Uninavarra, ColombiaA

*Author for correspondence:

danielcharry06@gmail.com 


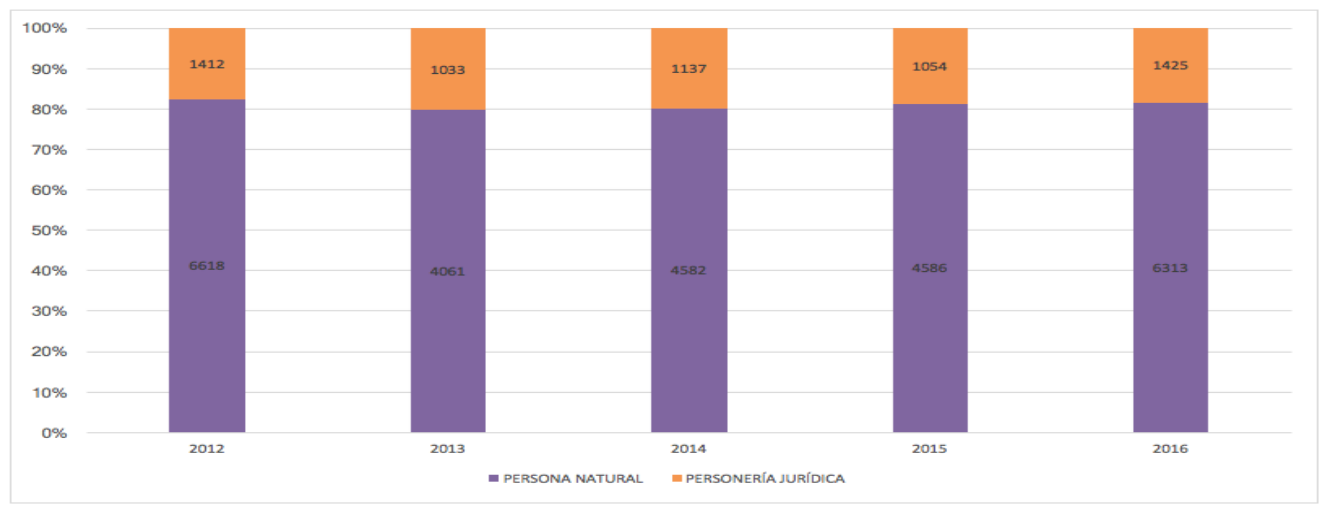

FIGURE 1. Type of company registration by period.

they cannot be considered current since economic conditions change rapidly over time.

Regarding the health sector, the dynamics of these companies are not yet established. Therefore, the objective of this study is to describe the survival factors of health companies that were included in the National Market Register between 2012 to 2016 in a southern state of Colombia.

\section{Methods}

A retrospective observational descriptive study was performed; the source of information was a national database "Registro Único Comercial y Social - RUES"; taking into account only registered health insurance companies between 2012 to 2016, their economic activity, size and location.

Data analysis was restricted to companies with a legal status and registered under human health care and social assistance as their main economic activity. The analysis was performed for the Uninavarra Research Center team using the statistical program IBM-SPSS 23 version.

Central tendency and dispersion measurements were used for the quantitative variables; in addition, bivariate analysis was performed to correlate economic activity, size and location. Various statistical confidence tests were applied, such as spearman Rho and Chi2 (x2).

\section{- Inclusion and exclusion criteria}

Company creation date was determined with the registration database and company death whenever it disappear from database, that could be for cancellation of the registration or due to no new updates of its registration in the following years. Every missing data information of the companies was not considerate for de study.

\section{Results}

Between 2012 to 2016 a total of 51114 companies were registered, $63.04 \%$ of those were subscribed for a natural or legal person. From these productive units $18.81 \%$ were legal entities, and the constitution average was $18.97 \%$, with constitution means ranged between $17 \%$ to $20 \%$ (FIGURE 1).

For the period of 2016 a total of $72.61 \%$ of companies were found registered and with an updated commercial register. Between 2012 - 2015 period $64.19 \%$ ( $n=2$ 976) updated their commercial registry, conforming $67.62 \%$ of the total active companies for 2016 (TABLE 1).

Data showed that during 2012-2016 the updating of the merchant registry was found to be inversely proportional with the time of creation. Updating for the first period companies was $41,50 \%(n=586)$, for the second period $66,51 \%(\mathrm{n}=687)$, for the third period was $73,97 \%(\mathrm{n}=1137)$ and for the fourth was $81,78 \%(\mathrm{n}=862)$ (TABLE 1$)$.

During the study period, $67.94 \%$ of the companies registered were created in the northern región of the state, of which $71.78 \%$ were still active at the end of 2016, additionally presenting the lowest renovation rate compared to the other zones of the state, the other regions of the state presented different behavior (TABLE 2).

At the end of 2016, 70, 32\% of the companies registered had also another economic activity registered. The most common was other 


\begin{tabular}{|c|c|c|c|c|}
\hline $\begin{array}{l}\text { Registration } \\
\text { year }\end{array}$ & Registered & $\begin{array}{l}\text { Renewed and } \\
\text { registered in } 2016\end{array}$ & $\begin{array}{l}\% \text { renewed and } \\
\text { registered in } 2016 \text { per period }\end{array}$ & $\begin{array}{l}\% \text { renewed and } \\
\text { registered to } 2016 \text { on the total }\end{array}$ \\
\hline 2012 & 1412 & 586 & $41.50 \%$ & $13.32 \%$ \\
\hline 2013 & 1033 & 687 & $66.51 \%$ & $15.61 \%$ \\
\hline 2014 & 1137 & 841 & $73.97 \%$ & $19.11 \%$ \\
\hline 2015 & 1054 & 862 & $81.78 \%$ & $19.59 \%$ \\
\hline 2016 & 1425 & 1425 & $100 \%$ & $32.38 \%$ \\
\hline Grand Total & 6061 & 4401 & $72.61 \%$ & $100 \%$ \\
\hline
\end{tabular}

\section{Table 2. Geographical distribution of companies registered during 2012 to 2016 periods}

\section{among the state of Huila-Colombia.}

\begin{tabular}{|c|c|c|c|c|c|}
\hline Subregion & Registered & $\begin{array}{c}\text { Renewed and } \\
\text { Registered in } \\
\mathbf{2 0 1 6}\end{array}$ & \% Registered & $\begin{array}{c}\text { \% renewed and } \\
\text { Registered by } \\
\text { area }\end{array}$ & $\begin{array}{c}\text { \% renewed and } \\
\text { registered } \\
\text { with respect to the total }\end{array}$ \\
\hline Center & 605 & 435 & $9.98 \%$ & $71.90 \%$ & $9.88 \%$ \\
\hline North & 4118 & 2956 & $67.94 \%$ & $71.78 \%$ & $67.17 \%$ \\
\hline West & 445 & 341 & $7.34 \%$ & $76.63 \%$ & $7.75 \%$ \\
\hline South & 893 & 669 & $14.73 \%$ & $74.92 \%$ & $15.20 \%$ \\
\hline Grand Total & 6061 & 4401 & $100 \%$ & $72.61 \%$ & $100 \%$ \\
\hline
\end{tabular}

\section{Table 3. Distribution of companies by size and economic sector.}

\begin{tabular}{|c|c|c|c|c|c|c|c|}
\hline \multirow{2}{*}{ Section } & \multirow{2}{*}{ Description } & \multicolumn{4}{|c|}{ Company size $^{*}$} & \multirow{2}{*}{ Total } & \multirow{2}{*}{$\begin{array}{l}\text { Participation } \\
\text { by sector }(\%)\end{array}$} \\
\hline & & Large & Medium & Micro & Small & & \\
\hline A & $\begin{array}{l}\text { Agriculture, livestock, hunting, forestry } \\
\text { and fishing }\end{array}$ & & 4 & 421 & 12 & 439 & $9.98 \%$ \\
\hline B & Exploitation of mines and quarries & & & 40 & 2 & 43 & $0.98 \%$ \\
\hline $\mathrm{C}$ & Manufacturing industries & & 1 & 238 & 22 & 262 & $5.95 \%$ \\
\hline $\mathrm{D}$ & $\begin{array}{l}\text { Water distribution; evacuation and } \\
\text { treatment of wastewater, waste } \\
\text { management and environmental } \\
\text { sanitation activities }\end{array}$ & & 1 & 48 & & 51 & $1.16 \%$ \\
\hline $\mathrm{F}$ & Building & 2 & 8 & 445 & 39 & 496 & $11.27 \%$ \\
\hline G & $\begin{array}{l}\text { Wholesale and Retail; repair of motor } \\
\text { vehicles and motorcycles }\end{array}$ & 1 & 3 & 596 & 42 & 647 & $14.70 \%$ \\
\hline $\mathrm{H}$ & Transportation and storage & & & 109 & 15 & 124 & $2.82 \%$ \\
\hline I & Accommodation and food services & & & 112 & 6 & 121 & $2.75 \%$ \\
\hline J & Information and communications & & & 118 & & 118 & $2.68 \%$ \\
\hline K & Financial and insurance activities & & & 58 & 3 & 62 & $1.41 \%$ \\
\hline $\mathrm{L}$ & Real estate activities & & & 58 & 7 & 65 & $1.48 \%$ \\
\hline M & $\begin{array}{l}\text { Professional, scientific and technical } \\
\text { activities }\end{array}$ & & 1 & 478 & 9 & 491 & $11.16 \%$ \\
\hline $\mathrm{N}$ & $\begin{array}{l}\text { Administrative and support services } \\
\text { activities }\end{array}$ & & 1 & 161 & 11 & 174 & $3.95 \%$ \\
\hline$\tilde{\mathrm{N}}$ & $\begin{array}{l}\text { Public administration and defense; } \\
\text { compulsory social security plans }\end{array}$ & & & 35 & 1 & 38 & $0.86 \%$ \\
\hline $\mathrm{O}$ & Education & & 1 & 58 & 2 & 64 & $1.45 \%$ \\
\hline $\mathrm{P}$ & $\begin{array}{l}\text { Human health care and social } \\
\text { assistance activities }\end{array}$ & 1 & 1 & 140 & 12 & 154 & $3.50 \%$ \\
\hline Q & $\begin{array}{l}\text { Artistic, entertainment and recreation } \\
\text { activities }\end{array}$ & & 3 & 23 & 1 & 27 & $0.61 \%$ \\
\hline $\mathrm{R}$ & Other service activities & & & 945 & 4 & 1022 & $23.22 \%$ \\
\hline $\mathrm{T}$ & Without activity & & & 3 & & 3 & $0.07 \%$ \\
\hline & Grand Total & 4 & 24 & 4086 & 188 & 4401 & $100 \%$ \\
\hline
\end{tabular}

*The total value of the assets of the companies was taken into account. Medium with assets above 5,000 SMMLV and up to 30,000 SMMLV. Small with assets above 500 SMMLV and up to 5,000 SMMLV. The micro are companies with assets up to 500 SMMLV.

activities related to health care with $23.22 \%$, wholesale trade in $14.7 \%$, construction
$11.27 \%$, professional, scientific and technical activities $11-16 \%$ and agriculture, livestock, 
hunting, forestry and fishing $9.98 \%$. The most common size of the companies related were the micro-companies, that corresponded to $92.84 \%$ $(n=4,086)$ of the total (TABLE 3).

About $45 \%$ of the companies from the health care and social assistance in the study period corresponded to a legal entity with an average of $45.61 \%$ of constitution per period. The lowest companies under this legal status $(31 \%)$ were in the 2016 period, while the highest creation of companies of this type $(57.50 \%)$ were the 2014 period (TABLE 4).
During the study period $81.91 \%$ ( $\mathrm{n}=154)$ of the registered companies renewed their registration title for the year 2016 with a mean of 78.43\% between 2012 - 2015 periods (TABLE 5). The companies registered during the 2012 to 2015 periods also presented a similar average of renovation ranging between $82.58 \%$ and 84.78 (TABLE 6).

Of the companies incorporated in 2012, $72.2 \%(n=526)$ renewed their registration in all periods of the study, $5.5 \%(\mathrm{n}=2)$ did not renew in any period and $22.2 \%(\mathrm{n}=8)$. They renewed

\begin{tabular}{c|c|c|c|c|c|c|}
\hline $\begin{array}{c}\text { Table 4. Type of company registration by period. } \\
\text { Period }\end{array}$ & Person & Legal satus & Total firms & \% person & \% Legal status & \% Legal status per period \\
\hline 2012 & 46 & 36 & 82 & $11.00 \%$ & $8.61 \%$ & $43.90 \%$ \\
\hline 2013 & 37 & 44 & 81 & $8.85 \%$ & $10.53 \%$ & $54.32 \%$ \\
\hline 2014 & 34 & 46 & 80 & $8.13 \%$ & $11.00 \%$ & $57.50 \%$ \\
\hline 2015 & 44 & 31 & 75 & $10.53 \%$ & $7.42 \%$ & $41.33 \%$ \\
\hline 2016 & 69 & 31 & 100 & $16.51 \%$ & $7.42 \%$ & $31.00 \%$ \\
\hline Grand total & 230 & 188 & 418 & $55.02 \%$ & $44.98 \%$ & $45.61 \%$ \\
\hline
\end{tabular}

\begin{tabular}{|c|c|c|c|c|}
\hline Registration year & Registered & $\begin{array}{c}\text { Renewed and } \\
\text { Registered in } 2016\end{array}$ & $\begin{array}{l}\text { \% Renewed and } \\
\text { Registered in } 2016 \text { per period }\end{array}$ & $\begin{array}{l}\text { \% Renewed and } \\
\text { Registered in } 2016\end{array}$ \\
\hline 2012 & 36 & 26 & $72.11 \%$ & $16.88 \%$ \\
\hline 2013 & 44 & 33 & $75.00 \%$ & $21.43 \%$ \\
\hline 2014 & 46 & 38 & $82.61 \%$ & $24.68 \%$ \\
\hline 2015 & 31 & 26 & $83.87 \%$ & $16.88 \%$ \\
\hline 2016 & 31 & 31 & $100 \%$ & $20.13 \%$ \\
\hline Grand total & 188 & 154 & $81.91 \%$ & $100 \%$ \\
\hline
\end{tabular}

\begin{tabular}{c|c|c|c|c|c|}
\hline $\begin{array}{c}\text { Table 6. Company register Updating by period. } \\
\text { Constitution } \\
\text { period }\end{array}$ & \multicolumn{5}{c|}{$\begin{array}{c}\text { Renewal Period } \\
\text { Renerage number of } \\
\text { Companies renewed }\end{array}$} \\
\hline 2012 & 2013 & 2014 & 2015 & 2016 & $83.33 \%$ \\
\hline 2013 & $94.44 \%$ & $86.11 \%$ & $80.56 \%$ & $72.22 \%$ & $82.58 \%$ \\
\hline 2014 & & $88.64 \%$ & $84.09 \%$ & $75.00 \%$ & $84.78 \%$ \\
\hline 2015 & & & $86.96 \%$ & $82.61 \%$ & $83.87 \%$ \\
\hline
\end{tabular}

\begin{tabular}{|c|c|c|c|c|}
\hline Constitution year & $\begin{array}{l}\text { Total companies } \\
\text { incorporated }\end{array}$ & Continuous renewal & Without renewal & Some renovation \\
\hline 2012 & 36 & 26 & 2 & 8 \\
\hline 2013 & 44 & 33 & 5 & 6 \\
\hline 2014 & 46 & 38 & 6 & 2 \\
\hline 2015 & 31 & 26 & 5 & 0 \\
\hline Total & 188 & 123 & 18 & 16 \\
\hline Constitution year & $\begin{array}{l}\% \text { Continuous } \\
\text { renewal }\end{array}$ & $\%$ Without renewal & $\%$ Some renovation & $\begin{array}{l}\text { \% Companies with } \\
\text { renewal to } 2016\end{array}$ \\
\hline 2012 & $72.2 \%$ & $5.5 \%$ & $22.2 \%$ & $72.11 \%$ \\
\hline 2013 & $75 \%$ & $11.36 \%$ & $13.63 \%$ & $75.00 \%$ \\
\hline 2014 & $82.6 \%$ & $13.04 \%$ & $4.34 \%$ & $82.61 \%$ \\
\hline 2015 & $83.87 \%$ & $16.13 \%$ & & $83.87 \%$ \\
\hline Average & $78.42 \%$ & $11.51 \%$ & $13.39 \%$ & $78.40 \%$ \\
\hline
\end{tabular}


in one of the periods described. The information discriminated from the behavior of the renewals by enrollment period is found in TABLE 7 . Additionally, it was evidenced that the behavior of non-renewal of the registry increased exponentially period after period where in the first year it was $23.54 \%, 32.87 \%$ for the second, $42.99 \%$ for the third and $58.50 \%$ for the fourth.

Most of the companies from the 2012 group $72.2 \%(\mathrm{n}=526)$ renewed their registration at all periods, $22.2 \%(\mathrm{n}=8)$ updated their registration only for one period, and 5.5\% ( $\mathrm{n}=2)$ did not updated at any other period. Also, there was a relationship between time of registry and updating, where the oldest registries only renewed in $23.54 \%, 32.87 \%$ for the second, $42.99 \%$ for the third and $58.50 \%$ for the fourth registry period (TABLE 7).

A total of $92.55 \%(n=174)$ companies were micro-companies in size. From those companies, $80.46 \%(n=140)$ remained in activities until the end of the 2016 period (TABLE 8).

The state region with the bigger number

\begin{tabular}{|c|c|c|c|c|c|}
\hline Table 8. Company register Updating by period by size. \\
\hline Size & Registration & $\begin{array}{c}\text { \% Registered } \\
\text { companies }\end{array}$ & $\begin{array}{c}\text { Active } \\
\mathbf{2 0 1 6}\end{array}$ & $\begin{array}{c}\text { \% Active companies } \\
\mathbf{2 0 1 6}\end{array}$ & $\begin{array}{c}\text { \% Companies } \\
\text { renewed by size }\end{array}$ \\
\hline Large Company & 1 & $0.53 \%$ & 1 & $0.65 \%$ & $100 \%$ \\
\hline Medium Company & 1 & $0.53 \%$ & 1 & $0.65 \%$ & $100 \%$ \\
\hline Micro Company & 174 & $92.55 \%$ & 140 & $90.91 \%$ & $80.46 \%$ \\
\hline Small company & 12 & $6.38 \%$ & 12 & $7.79 \%$ & $100 \%$ \\
\hline Grand total & 188 & $100.00 \%$ & 154 & $100 \%$ & $81.91 \%$ \\
\hline
\end{tabular}

\section{Table 9. Company registration and updating by state subregion.}

\begin{tabular}{|c|c|c|c|c|c|}
\hline Subregion & Registration & $\begin{array}{c}\text { \% registered } \\
\text { companies }\end{array}$ & $\begin{array}{c}\text { Active } \\
\mathbf{2 0 1 6}\end{array}$ & $\begin{array}{c}\text { \% companies renewed by } \\
\text { sub-region }\end{array}$ & $\begin{array}{c}\text { active companies } \\
\mathbf{2 0 1 6}\end{array}$ \\
\hline Center & 8 & $4.26 \%$ & 6 & $75.00 \%$ & $3.90 \%$ \\
\hline North & 145 & $77.13 \%$ & 121 & $83.45 \%$ & $78.57 \%$ \\
\hline West & 12 & $6.38 \%$ & 10 & $83.33 \%$ & $6.49 \%$ \\
\hline South & 23 & $12.23 \%$ & 17 & $73.91 \%$ & $11.04 \%$ \\
\hline Grand Total & 188 & $100 \%$ & 154 & $81.91 \%$ & $100 \%$ \\
\hline
\end{tabular}

\begin{tabular}{|c|c|c|c|c|c|c|}
\hline Economic activity & 2012 & 2013 & 2014 & 2015 & 2016 & $\begin{array}{l}\text { Average } \\
\text { registration }\end{array}$ \\
\hline $\begin{array}{l}\text { Activities of medical practice without } \\
\text { hospitalization }\end{array}$ & $27.78 \%$ & $43.18 \%$ & $52.17 \%$ & $54.84 \%$ & $41.94 \%$ & $43.98 \%$ \\
\hline Other activities of human health care & $30.56 \%$ & $15.91 \%$ & $10.87 \%$ & $19.35 \%$ & $19.35 \%$ & $19.21 \%$ \\
\hline Activities of the dental practice & $13.89 \%$ & $11.36 \%$ & $15.22 \%$ & $6.45 \%$ & $9.68 \%$ & $11.32 \%$ \\
\hline Diagnostic support activities & $8.33 \%$ & $13.64 \%$ & $10.87 \%$ & $3.23 \%$ & $9.68 \%$ & $9.15 \%$ \\
\hline Therapeutic support activities & $11.11 \%$ & $11.36 \%$ & $4.35 \%$ & $3.23 \%$ & $12.90 \%$ & $8.59 \%$ \\
\hline Generalized residential medical care activities & $2.78 \%$ & $0.00 \%$ & $4.35 \%$ & $0.00 \%$ & $0.00 \%$ & $1.85 \%$ \\
\hline $\begin{array}{l}\text { Other social assistance activities without } \\
\text { accommodation }\end{array}$ & $0.00 \%$ & $4.55 \%$ & $0.00 \%$ & $3.23 \%$ & $0.00 \%$ & $1.55 \%$ \\
\hline $\begin{array}{l}\text { Activities of hospitals and clinics with } \\
\text { hospitalization }\end{array}$ & $2.78 \%$ & $0.00 \%$ & $0.00 \%$ & $3.23 \%$ & $3.23 \%$ & $1.43 \%$ \\
\hline $\begin{array}{l}\text { Residential care activities for the care of } \\
\text { patients with mental retardation mental } \\
\text { illness and consumption of psychoactive } \\
\text { substances }\end{array}$ & $0.00 \%$ & $0.00 \%$ & $0.00 \%$ & $6.45 \%$ & $0.00 \%$ & $1.29 \%$ \\
\hline $\begin{array}{l}\text { Other care activities in institutions with } \\
\text { accommodation }\end{array}$ & $0.00 \%$ & $0.00 \%$ & $0.00 \%$ & $0.00 \%$ & $3.23 \%$ & $0.65 \%$ \\
\hline $\begin{array}{l}\text { Care activities in institutions for the care of } \\
\text { the elderly and / or disabled }\end{array}$ & $2.78 \%$ & $0.00 \%$ & $0.00 \%$ & $0.00 \%$ & $0.00 \%$ & $0.43 \%$ \\
\hline $\begin{array}{l}\text { Social assistance activities without } \\
\text { accommodation for the elderly and disabled }\end{array}$ & $0.00 \%$ & $0.00 \%$ & $2.17 \%$ & $0.00 \%$ & $0.00 \%$ & $0.56 \%$ \\
\hline Grand Total & $100 \%$ & $100 \%$ & $100 \%$ & $100 \%$ & $100 \%$ & \\
\hline
\end{tabular}


of companies registered as new was the north region with $77.13 \%$ of the total, and maintaining its representation in the number of active companies in 2016 with $78.57 \%$ of the total. The average turnover of companies in the other sub regions was 78.92\% (TABLE 9).

The registration of new companies for non- hospitalization health care remained constant over all periods of the study, with an average enrollment of $43.98 \%$, followed by other activities of human health care $19.21 \%$, and $11.32 \%$ for dental practice (TABLE 10).

The most part of the companies were related to basic health centers $74.47 \%$, and the rest Table 11. Company registration by economic activity and size.

\begin{tabular}{|c|c|c|c|c|c|c|}
\hline Economic activity & $\begin{array}{l}\text { Large } \\
\text { Company }\end{array}$ & $\begin{array}{l}\text { Medium } \\
\text { Company }\end{array}$ & $\begin{array}{l}\text { Micro- } \\
\text { company }\end{array}$ & $\begin{array}{l}\text { Small } \\
\text { company }\end{array}$ & $\begin{array}{l}\text { Grand } \\
\text { Total }\end{array}$ & $\begin{array}{l}\text { Participation } \\
\text { by activity }\end{array}$ \\
\hline Diagnostic support activities & & & 15 & 3 & 18 & $9.57 \%$ \\
\hline Therapeutic support activities & & & 14 & 2 & 16 & $8.51 \%$ \\
\hline $\begin{array}{l}\text { Social assistance activities without } \\
\text { accommodation for the elderly and } \\
\text { disabled }\end{array}$ & & & 1 & & 1 & $0.53 \%$ \\
\hline $\begin{array}{l}\text { Care activities in institutions for the care } \\
\text { of the elderly and / or disabled }\end{array}$ & & & 1 & & 1 & $0.53 \%$ \\
\hline $\begin{array}{l}\text { Residential care activities for the care } \\
\text { of patients with mental retardation } \\
\text { mental illness and consumption of } \\
\text { psychoactive substances }\end{array}$ & & & 2 & & 2 & $1.06 \%$ \\
\hline $\begin{array}{l}\text { Generalized residential medical care } \\
\text { activities }\end{array}$ & & & 3 & & 3 & $1.60 \%$ \\
\hline $\begin{array}{l}\text { Activities of hospitals and clinics with } \\
\text { hospitalization }\end{array}$ & & 1 & 1 & 1 & 3 & $1.60 \%$ \\
\hline $\begin{array}{l}\text { Activities of medical practice without } \\
\text { hospitalization }\end{array}$ & & & 77 & 6 & 83 & $44.15 \%$ \\
\hline Activities of the dental practice & & & 22 & & 22 & $11.70 \%$ \\
\hline $\begin{array}{l}\text { Other social assistance activities } \\
\text { without accommodation }\end{array}$ & & & 3 & & 3 & $1.60 \%$ \\
\hline Other activities of human health care & 1 & & 34 & & 35 & $18.62 \%$ \\
\hline $\begin{array}{l}\text { Other care activities in institutions with } \\
\text { accommodation }\end{array}$ & & & 1 & & 1 & $0.53 \%$ \\
\hline Grand Total & 1 & 1 & 174 & 12 & 188 & $100.00 \%$ \\
\hline
\end{tabular}

\begin{tabular}{|c|c|c|c|c|}
\hline Economic activity & Registered & $\begin{array}{l}\% \text { registered } \\
\text { participation }\end{array}$ & $\begin{array}{l}\text { Renewed and } \\
\text { registered in } 2016\end{array}$ & $\begin{array}{c}\% \\
\text { renovated }\end{array}$ \\
\hline $\begin{array}{l}\text { Activities of medical practice without } \\
\text { hospitalization }\end{array}$ & 83 & $44,15 \%$ & 71 & $85,54 \%$ \\
\hline Other activities of human health care & 35 & $18.62 \%$ & 24 & $68.57 \%$ \\
\hline Activities of the dental practice & 22 & $11.70 \%$ & 18 & $81.82 \%$ \\
\hline Diagnostic support activities & 18 & $9.57 \%$ & 15 & $83.33 \%$ \\
\hline Therapeutic support activities & 16 & $8.51 \%$ & 13 & $81.25 \%$ \\
\hline Generalized residential medical care activities & 3 & $1.60 \%$ & 3 & $100.00 \%$ \\
\hline $\begin{array}{l}\text { Other social assistance activities without } \\
\text { accommodation }\end{array}$ & 3 & $1.60 \%$ & 3 & $100.00 \%$ \\
\hline $\begin{array}{l}\text { Activities of hospitals and clinics with } \\
\text { hospitalization }\end{array}$ & 3 & $1.60 \%$ & 3 & $100.00 \%$ \\
\hline $\begin{array}{l}\text { Residential care activities for the care of patients } \\
\text { with mental retardation mental illness and } \\
\text { consumption of psychoactive substances }\end{array}$ & 2 & $1.06 \%$ & 1 & $50.00 \%$ \\
\hline $\begin{array}{l}\text { Other care activities in institutions with } \\
\text { accommodation }\end{array}$ & 1 & $0.53 \%$ & 1 & $100.00 \%$ \\
\hline $\begin{array}{l}\text { Care activities in institutions for the care of the } \\
\text { elderly and / or disabled }\end{array}$ & 1 & $0.53 \%$ & 1 & $100.00 \%$ \\
\hline $\begin{array}{l}\text { Social assistance activities without } \\
\text { accommodation for the elderly and disabled }\end{array}$ & 1 & $0.53 \%$ & 1 & $100.00 \%$ \\
\hline Grand Total & 188 & $100 \%$ & 154 & $81.91 \%$ \\
\hline
\end{tabular}


corresponded to other activities of human health care and dental practice. The largest portion of size companies were micro companies $92.55 \%$ $(\mathrm{n}=174)$, and its distribution corresponds, in the same order, with the activities of most common participation (TABLE 11).
The $36.3 \%$ of the economic activities in the health care sector registered during all the periods were diagnostic support, therapeutic support, day care management of patients, and those related to the dental practice. As the periods are passing we found decreasing

Table 13. Company registered and updated for the 2016 period by economic activity.

\begin{tabular}{|c|c|c|c|c|}
\hline Economic activity & 2012 & 2013 & 2014 & 2015 \\
\hline Diagnostic support activities & $100.00 \%$ & $66.67 \%$ & $80.00 \%$ & $100.00 \%$ \\
\hline Therapeutic support activities & $75.00 \%$ & $60.00 \%$ & $100.00 \%$ & $100.00 \%$ \\
\hline $\begin{array}{l}\text { Social assistance activities without accommodation for the } \\
\text { elderly and disabled }\end{array}$ & & & $100.00 \%$ & \\
\hline $\begin{array}{l}\text { Care activities in institutions for the care of the elderly and / or } \\
\text { disabled }\end{array}$ & $100.00 \%$ & & & \\
\hline $\begin{array}{l}\text { Residential care activities for the care of patients with mental } \\
\text { retardation mental illness and consumption of psychoactive } \\
\text { substances }\end{array}$ & & & & $50.00 \%$ \\
\hline Generalized residential medical care activities & $100.00 \%$ & & $100.00 \%$ & \\
\hline Activities of hospitals and clinics with hospitalization & $100.00 \%$ & & & $100.00 \%$ \\
\hline Activities of medical practice without hospitalization & $80.00 \%$ & $78.95 \%$ & $83.33 \%$ & $88.24 \%$ \\
\hline Activities of the dental practice & $80.00 \%$ & $100.00 \%$ & $57.14 \%$ & $100.00 \%$ \\
\hline Other social assistance activities without accommodation & & $100.00 \%$ & & $100.00 \%$ \\
\hline Other activities of human health care & $45.45 \%$ & $57.14 \%$ & $100.00 \%$ & $66.67 \%$ \\
\hline Grand Total & $72.22 \%$ & $75.00 \%$ & $82.61 \%$ & $83.87 \%$ \\
\hline
\end{tabular}

Table 14. Registered and updated companies for the 2016 period by economic activity and size

\begin{tabular}{|c|c|c|c|c|c|c|}
\hline Economic activity & $\begin{array}{l}\text { Large } \\
\text { Company }\end{array}$ & $\begin{array}{l}\text { Medium } \\
\text { Company }\end{array}$ & $\begin{array}{l}\text { Micro- } \\
\text { company }\end{array}$ & $\begin{array}{c}\text { Small } \\
\text { company }\end{array}$ & Grand Total & $\begin{array}{l}\text { Participation by } \\
\text { activity }\end{array}$ \\
\hline Diagnostic support activities & & & 12 & 3 & 15 & $9.74 \%$ \\
\hline $\begin{array}{l}\text { Therapeutic support } \\
\text { activities }\end{array}$ & & & 11 & 2 & 13 & $8.44 \%$ \\
\hline $\begin{array}{l}\text { Social assistance activities } \\
\text { without accommodation for } \\
\text { the elderly and disabled }\end{array}$ & & & 1 & & 1 & $0.65 \%$ \\
\hline $\begin{array}{l}\text { Care activities in institutions } \\
\text { for the care of the elderly } \\
\text { and / or disabled }\end{array}$ & & & 1 & & 1 & $0.65 \%$ \\
\hline $\begin{array}{l}\text { Residential care activities } \\
\text { for the care of patients with } \\
\text { mental retardation mental } \\
\text { illness and consumption of } \\
\text { psychoactive substances }\end{array}$ & & & 1 & & 1 & $0.65 \%$ \\
\hline $\begin{array}{l}\text { Generalized residential } \\
\text { medical care activities }\end{array}$ & & & 3 & & 3 & $1.95 \%$ \\
\hline $\begin{array}{l}\text { Activities of hospitals and } \\
\text { clinics with hospitalization }\end{array}$ & & 1 & 1 & 1 & 3 & $1.95 \%$ \\
\hline $\begin{array}{l}\text { Activities of medical practice } \\
\text { without hospitalization }\end{array}$ & & & 65 & 6 & 71 & $46.10 \%$ \\
\hline $\begin{array}{l}\text { Activities of the dental } \\
\text { practice }\end{array}$ & & & 18 & & 18 & $11.69 \%$ \\
\hline $\begin{array}{l}\text { Other social assistance } \\
\text { activities without } \\
\text { accommodation }\end{array}$ & & & 3 & & 3 & $1.95 \%$ \\
\hline $\begin{array}{l}\text { Other activities of human } \\
\text { health care }\end{array}$ & 1 & & 23 & & 24 & $15.58 \%$ \\
\hline $\begin{array}{l}\text { Other care activities } \\
\text { in institutions with } \\
\text { accommodation }\end{array}$ & & & 1 & & 1 & $0.65 \%$ \\
\hline Grand Total & 1 & 1 & 140 & 12 & 154 & $100 \%$ \\
\hline
\end{tabular}


number of companies registered, for the 2012 period only $72 \%$ remained in activities in the 2016 period, and for the 2014 period around $80 \%$ remained in activities by the 2015 period (TABLE 12).

For the 2016 period $73.37 \%$ of the companies were registered for medical practice without hospitalization, other activities of human health care and activities of dental practice (TABLE 13).

The $90.90 \%(n=140)$ of the companies were micro companies in size, we found also that this kind of companies presented the bigger proportion of closure (TABLE 14).

\section{Conclusion}

Creation and sustainability of companies are indicators of development and economic growth in a region. In our study we found that, from a global view, companies that did not update their commercial registration were most micro and small companies in size also were the companies that did not update their merchant registry. In addition, companies registered as medium and large maintained had more updates of their mercantile registry without reporting a cessation of activities. Therefore, the smaller the companies are more difficult it becomes to maintain activities over time. Similar behavior was explained for Martínez [30] and Hernández [31] who identified that the small companies have more probabilities of staying actives that other large ones.

We found a direct association between size of the company and economic activity. Activities related to the smaller companies were related to activities of medical practice without hospitalization, dental practice and other related with health care. Similar behavior was found for companies that updated their registries, where the activities that had the most renewal of companies were activities of medical practice without hospitalization, diagnostic support activities and activities of dental practice. In addition, there was a direct association between the type of registered economic activity and the number of companies registered for each of them. Economic activities with less creation of new companies did not present cessation of activities or intermittency in the update of their merchant registry; but for those with high number of new registers presented more closure/cessation of activities. In different way, in Colombia, the level of concession of companies in economic subsectors is related to the probability of survival demonstrating that the companies registered in the sub-sectors with high levels are at greater risk of leaving the market [27-28,21-31].

These results have different contributions: for practical of business administration, for economic and management literature and for regional politics decision. Also, this study shows the business landscape of the health sector in a region of southern Colombia, serving as a national and international benchmark and a baseline for future studies.

Our conclusions in this study could help others for carrying out projects, strategies and interventions that encourage the creation of companies and strengthen their sustainability and success in a similar economic environment.

\section{Disclosure}

The authors declare no conflict of interest, regarding the publication of this paper. 


\section{REFERENCES}

Barón G. Cuentas de salud de Colombia 1993-2003: el gasto nacional en salud y su financiamiento. Bogotá: Impresol (2007).

Hernández M. Reforma sanitaria, equidad y derecho a la salud en Colombia. Cadernos de Saúde Pública 18(4), 9911001 (2002).

Barón G. Gasto Nacional en Salud de Colombia 1993-2003: Composición y Tendencias. Rev. Salud Pública 9(2), 167179 (2007).

Departamento Administrativo Nacional de Estadísticas (DANE). Censo económico. Bogotá (2005).

Mills D, Timmins J. Firm Dynamics in New Zealand: A Comparative Analysis with OECD Countries. New Zealand treasury working paper 04/11 (2004).

Johnson P. Targeting Firm Births and Economic Regeneration in a Lagging Region. Small Business Economics, 24(5), 451-464 (2005).

Franco M, Urbano D. El éxito de las PyMES en Colombia: un estudio de casos en el sector salud. Estudios gerenciales 26(114), 77-97 (2010).

Bartelsman E, Scarpetta S, Schivardi F. Comparative analysis of firm demographics and survival: micro-level evidence for the OECD countries. Industrial Corporate Change 14(3), 365-391 (2005).

Santarelli E, Vivarelli M. Entrepreneurship and the process of firms' entry, survival and growth. Industrial Corporate Change 16(3), 455-488 (2007).

Highfield R, Smiley R. New Business Starts and Economics Activity. Int. J. Industrial Organization 5(1), 51-66 (1987).

Audretsch D. New firm survival and the technological regime. Rev. Econ. Stat. 73(3), 441-450 (1991).
Audretsch D. Innovation, growth and survival. Int. J. Industrial Organization 13(4), 441-457 (1995).

Cefis E, Marsili O. Innovation premium and the survival of entrepreneurial firms in the Netherlands. Berlin: Springer (2006).

Holmes P, Hunt A, Stone I. An analysis of new firm survival using a hazard function. App. Econ. 42(2), 185195 (2010).

Huggins R, Prokop D, Thompson P. Entrepreneurship and the determinants of firm survival within regions: human capital, growth motivation and locational conditions. Entrepreneurship Reg. Dev. 29(3-4), 357-389 (2017).

Hall B. The Relationship between firm size and firm growth in the US manufacturing sector. J. Industrial Econ. 35(4), 583-606 (1987).

Evans D. The relationship between firm growth, size and age: estimates for 100 manufacturing industries. J. Industrial Econ. 35(4), 567-581 (1987).

Dunne T, Roberts M, Samuelson L. Patterns of Firm Entry and Exit in U.S. Manuacturing Industries. RAND J. Econ. 19(4), 495-515 (1988).

Bentzen J, Madsen E, Smith V. Do Firms Growth Rates Depend on Firm Size? Small Business Econ. 39(4), 937-947 (2012).

Barba G, Castellani D, Pieri F. Age and Firm Growth: Evidence from Three European Countries. Small Business Econ. 43(4), 823-837 (2014).

Hannan M, Carroll G. Dynamics of Organizational Populations. New York: Oxford University Press, 1992.

Audretsch D, Mahmood T. The Rate of Hazard Confronting New Firms and Plants in US Manufacturing. Rev. Industrial Organization 9(1), 41-56 (1994).
Levinthal D. Adaptation on Rugged Landscapes. Management Sci. 43(7), 934950 (1997).

Rauch A, Rijsdijk S. 2013. The Effects of General and Specific Human Capital on Long-term Growth and Failure of Newly Founded Businesses. Entrepreneurship Th. Pract. 37(4), 923-941 (2013).

Red de Cámaras de Comercio (Confecámaras). Determinantes de la supervivencia empresarial en Colombia. Bogotá (2017).

Montoya A, Montoya I, Castellanos O. Situación de la competitividad de las pyme en Colombia: elementos actuales y retos. Agronomía Colombiana 28(1), 107117 (2010).

Arias A, Quiroga R. Cese de actividades de las pymes en el área metropolitana de Cali (2000-2004): un análisis de supervivencia empresarial. Cuadernos de Administración 21(35), 249-277 (2008).

Parra J. Determinantes de la probabilidad de cierre de nuevas empresas en Bogotá. Revista de la facultad de ciencias económicas de la Universidad Militar Nueva Granada 19(1), 27-53 (2011).

Franco M, Urbano D. El éxito de las PyMES en Colombia: un studio de casos en el sector salud. Estudios gerenciales 26(114), 77-96 (2010).

Martínez A. Determinantes de la supervivencia de empresas industriales en el área metropolitana de Cali 1994- 2003. Revista Sociedad y Economía 11, 112-144 (2006).

Hernández C. Supervivencia de las microempresas en el departamento del Magdalena 2009-2012: un enfoque logístico. Perfil de Coyuntura Econ. 22, 197-204 (2013).

\section{This special issue on Current Trends in Clinical Research was edited by Dr. Mohamed Elsayed.}

